\title{
Pindar, Paean 6: Genre as Embodied Cultural Knowledge
}

\author{
Sarah Olsen*
}

By linking genre with occasion, scholars of Greek song invigorated the study of performance, ritual, and society in archaic and classical Greece. Recent attention to the reperformance of choral song has not diminished the importance of original performance context. Rather, studies of reperformance have consistently uncovered additional layers of meaning within individual songs, highlighting how the force of a song, a myth, or an image may shift in relation to different audiences and places of performance. ${ }^{1}$ In this chapter, however, I want to focus on what remains the same. How does an archaic choral song retain its fundamental generic quality across multiple occasions for performance? How might we preserve the insights gained from the "performance context" model of Greek song genre while also acknowledging the richness and complexity of reperformance? I will argue that understanding genre as a form of "embodied cultural knowledge" can explain how an archaic Greek choral song can be both an artifact of a specific performance occasion and a flexible expressive mode, adaptable to multiple situations and singers.

I owe the concept of "embodied cultural knowledge" to dance theorist Deirdre Sklar, whose observations I will discuss at greater length below. In essence, this phrase refers to the somatic and sensory experiences that an individual accrues in the course of living and moving within a particular societythe ways in which one's body both participates in and resists the process of acculturation. ${ }^{2}$ Given that the embodied presence and experience of both performers and audience members are a crucial element of Greek choral song as

* I am grateful to the editors of this volume, Meg Foster, Leslie Kurke, and Naomi Weiss, for their expert guidance and feedback in the preparation of this paper, and to all the participants in the 2015 conference on lyric genre at UC Berkeley, whose lively papers and stimulating questions have informed this work. Special thanks to Erin Lam for her insightful comments on an early draft of the project.

1 On performance context, occasion, and Greek song genre, see Bowie 1986; Nagy 1994-1995. On the reperformance of archaic choral song (especially Pindar) see, e.g., Currie 2004; Hubbard 2004; Kurke 2005; Morrison 2007, 2012; Athanassaki 2012.

2 Sklar 2008. 
an "occasional" phenomenon, I thus propose that genre was a form of embodied cultural knowledge for ancient Greeks. A married woman might remember what it felt like to perform as a young girl in a maiden chorus-nimble, active, perhaps filled with the simultaneous anticipation and anxiety of a particular performance and the major life transition it would facilitate. A frequent festival attendee could access the kinesthetic sensation-wearied limbs, the particular tilt of the climbing body — of approaching the steep shrine at Delphi. Terms like partheneion, prosodion, and paean—or related words and patterns of imagery-translate those visceral experiences into a common descriptive language. By the same token, an audience listening to the reperformance of a specific song-genre, even in a different setting and under different formal conditions, may be prompted to engage in sensorial memory of that genre as it would have originally been performed.

In this paper, I will focus on the paean, a notoriously difficult genre to define. Paeans have confounded categorization within the occasional model because of their apparent diversity and flexibility: while they were often performed by a chorus as part of religious festival, we also find evidence for paeans performed at symposia and in military contexts. ${ }^{3}$ In addition, a choral paean could be reperformed solo at a symposium, accomplishing the kind of shift in context and formal performance conditions that I am interested in exploring here. ${ }^{4}$ I will take Pindar's Paean 6 as my case study, though I intend my observations and claims to extend to Greek choral song in a broader sense as well. For that reason, I will begin by sketching out some salient features of choreia in general and Delphic paean specifically, drawing on the performance paradigm offered by the Homeric Hymn to Apollo. The Hymn offers one mythic account of the original paean performance at Delphi and demonstrates that choreia, as

3 For a thorough overview of the various performance contexts attested for the paean, see Rutherford 2001: $3^{-136 .}$

4 On the reperformance of paeans, see Rutherford 2001: 176, who posits three potential reperformance scenarios for Pindar's paeans: 1. repeated (presumably choral) performance in the same cult context as the original performance; 2. choral reperformance elsewhere; 3. performance at symposia (Rutherford gives as an example the performances of Simonides' mele referenced in Ar. Nub. 1355-1358, on which see also Nagy 1990: 107-108). On paeans at symposia more generally, Rutherford stresses the flexibility of the genre and suggests that a "symposium-paean" should not be considered categorically different from other forms, and that one kind (e.g., an apotropaic paean for Poseidon) could be reperformed at a symposium (2001: $\left.5^{-}-5^{2}\right)$. On the likely absence of dance when a choral paean is reperformed at symposia, see Rutherford 2001: 18. Athenian familiarity with Pindar's paeans is supported by the apparent intertextual relationship between Paean 9 and the parodos to Antigone, as discussed by Rutherford 2001: 199-200 and Budelmann 2013: 84. Sympotic reperformance would be the most likely scenario for preserving and disseminating that knowledge. 
an expressive and embodied ritual mode, creates a delicate balance between divine authority and the flexibility of individual experience. This is consistent with Sklar's conceptualization of embodied cultural knowledge, and at the end of my discussion of the Homeric Hymn, I will reflect further on the ramifications of her model for our understanding of Greek performance in general. I will then turn to Paean 6, first outlining the various possibilities for the performance and reperformance of this song and then zooming in on sympotic performance in particular, in order to illuminate how Paean 6 preserves and engages embodied choral experience even when reperformed in a sympotic setting. I will ultimately argue that Pindar uses the imagery of embodiment to allude to the invention of the paean itself, thereby reinstantiating the genre at each occasion of performance and drawing upon the audience's embodied knowledge in order to create generic continuity across differing performance contexts.

\section{Embodying the Divine: Paeanic Choreia at Delphi in the Homeric Hymn to Apollo}

The dynamics of embodiment at work in paeanic choreia in Paean 6 are largely consistent with the elements of choral performance as depicted elsewhere in early Greek literature, but one parallel is particularly illuminating: the representation of paeanic procession in the Homeric Hymn to Apollo. ${ }^{5}$ The final part of the Hymn to Apollo chronicles the god's arrival at Delphi and installation of a crew of Cretan sailors as his priests. This portion of the hymn also offers one account of the very first performance of paeans at Delphi, and as such, provides an illuminating intertext for Pindar's paean. In particular, the Hymn to Apollo emphasizes the god's power over the bodies of his followers, a potent vision of divine authority. At the same time, the Hymn stresses the preservation of individual autonomy and local ties within the larger confines of the chorus. It thereby sets out a reassuring ritual model for the performance of paeans at Delphi.

On one level, Apollo's treatment of the Cretan sailors in the Homeric Hymn is brutal. By steering them to Krisa, a port town close to Delphi, the god rup-

5 On the conceptualization of choreia in archaic and classical Greece, especially as a ritual and social institution, see Stehle 1997: 17-25; Kowalzig 2007b: 43-55; Kurke 2013a; Peponi 2013a. I understand the Homeric Hymn to Apollo as a paradigm of performance likely to be familiar to a range of audiences in the late archaic and classical periods (on the Hymn as a performance paradigm, see especially Lonsdale 1995). 
tures the men's ties to their homes and families. When the leader of the men addresses Apollo, he stresses their own lack of will. He claims, "we came here,

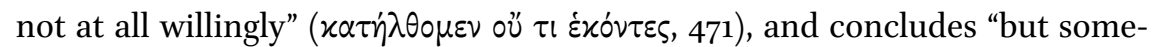
one of the immortals led us here, though we did not will it" ( $\dot{\lambda} \lambda \dot{\alpha} \tau \tau \varsigma \dot{\alpha} \theta \alpha \nu \alpha \dot{\alpha} \tau \nu$

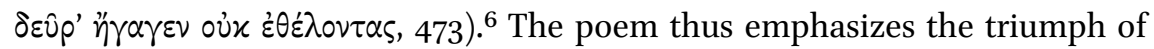
divine will over human intention, reminding its audience that men have no power to alter the plans of the gods. The Cretan leader also mentions his men's original plans, further highlighting Apollo's disruption of their lives. The man says, "for we were sailing the great sea, with another intention in mind, / to [go to] Pylos from Crete, where we claim our family (genos) is from" ( $\alpha \lambda \lambda \eta \eta \dot{\eta} \dot{\alpha}$

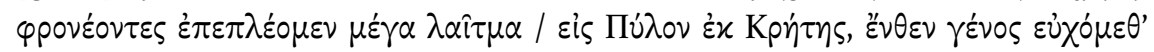
हival, 469-470). Even as he states their intended goal, the leader simultaneously emphasizes his men's origins. He reminds the god and the audience that

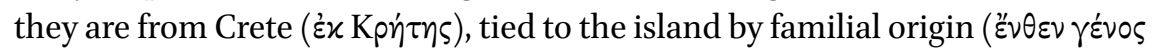

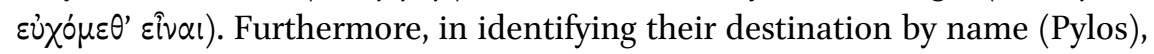
he contrasts it with their actual location (Krisa), a place unknown to them and unnamed. Apollo has interrupted a journey from familiar and familial territory to a known destination. His transportation of the Cretans to a place unknown and insignificant to them represents an ultimately permanent break from their local and personal priorities. It is no surprise, then, that the leader of the men interrogates Apollo, asking, "what people, what land is this? Which

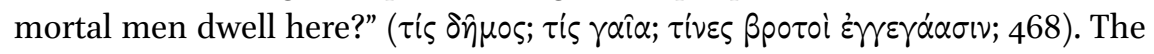
Cretans are disoriented, having arrived in an unfamiliar place. They have lost their bearings and must ask Apollo for even the most basic information about Krisa.

Apollo then informs the men that their affiliation with Knossos has ended, that their homes and wives are now lost to them:

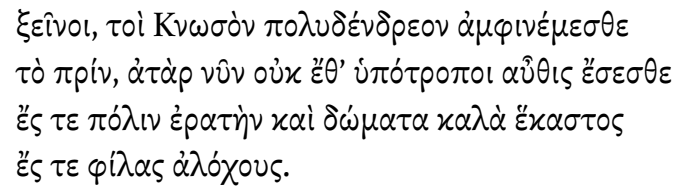

Strangers, you inhabited Knossos, thick with trees, previously, but now you will not return again

6 Translations, where not otherwise indicated, are my own. I have used Allen's (1912) text of the Homeric Hymn to Apollo. 
to the lovely city, and each to your fine halls and dear wives.

$$
475^{-478}
$$

The god acknowledges the men's affection for their homeland, remarking on

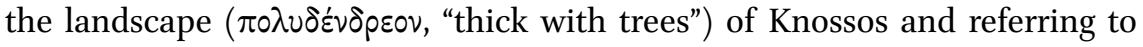

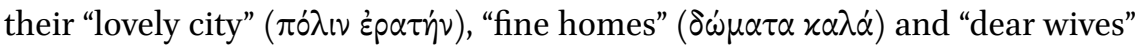
( $\varphi$ i $\lambda \alpha \varsigma \alpha \lambda{ }^{\prime}$ ó ovs). Yet even as he reminds the audience of the Cretans' connection to their homeland, he permanently severs those very ties. He emphasizes that their habitation of Knossos was "previous" ( $\tau \dot{0} \pi \rho i v)$, and that "they will not

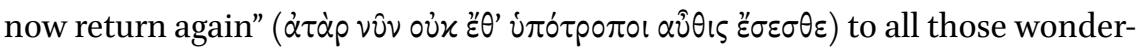
ful things.

If lines 388-485 were all that remained of the Homeric Hymn to Apollo, Delphi might seem a rather forbidding place. In this episode, Apollo presents himself as a god ready to disrupt local and personal ties and prevent his followers from returning home again. The foundation myth itself-Apollo's claim to Delphi and his importation of the Cretan sailors-is relentlessly focused on the needs of the god and his panhellenic shrine. How can such a totalizing account be reconciled with the likely realities of Apolline worship at Delphi? As Paean 6 itself demonstrates, Delphi would have had to accommodate worshippers from a variety of geographic locations and subgroup affiliations, the vast majority of whom would not, like the Cretan sailors in the Homeric Hymn to Apollo, remain permanently at Delphi as Apollo's priests. ${ }^{7}$ Rather, they would hope and plan to return home safely to their own towns or cities.

The representation of ritual procession in the Homeric Hymn ameliorates the complete rupture of the local and the personal accomplished by Apollo's initial relocation of the Cretan sailors. The poem thus offers a model of such ritual that supports and maintains local and personal identity while still emphasizing the ultimate authority of the god.

After informing the men of their permanent resettlement, Apollo gives them a set of specific instructions for prayer, sacrifice, feast, libations, and, finally, a musical procession to Delphi itself (487-501). The Cretans follow Apollo's instructions. Yet, after the procession has taken place, the leader of the Cretans again questions Apollo, emphasizing his local and personal affiliations just as he did in his first address to the god, prior to participation in the ordained ritual

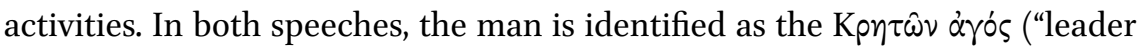

7 On the likely original performance context of Paean 6, see Kurke 2005. On the performance of paeans at Delphi in general, see Rutherford 2001: 24-29. 
of the Cretans," 463 and 525). When the man first speaks, this label seems natural enough - he is the preeminent figure among a group of men originating on the island of Crete. Yet by the time he speaks again, Apollo has informed the men that they will never return to Knossos, effectively stripping them of their local affiliations. The persistence of this marker of personal and local identity

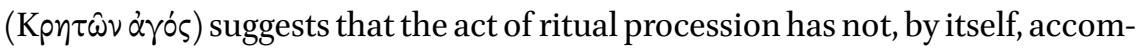
plished Apollo's goals. The man continues to be the leader of the Cretans, not yet a Delphic priest.

The poem also creates distinct spheres of leadership for both the Cretan man and the god himself. The leader of the Cretans is persistently referred to as such

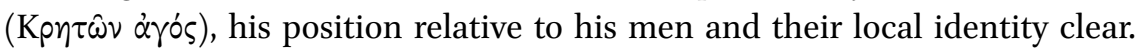
Yet while the noun àós marks the man, Apollo is repeatedly characterized by forms of the verb $\alpha \gamma \omega$. The Cretans acknowledge that the god "had led them

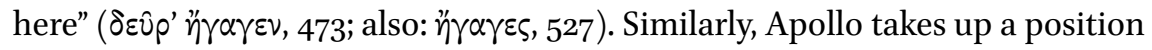
of leadership in the procession:

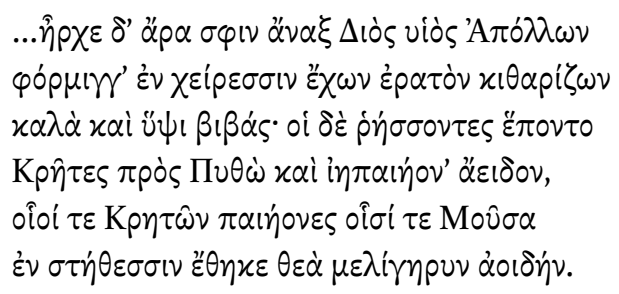

And the lord Apollo, the son of Zeus, began for them, having in his hands a lovely lyre, strumming well and stepping high. And the Cretans followed, stamping their feet, toward Pytho and they were singing a paean, and they were like paeans ${ }^{8}$ of the Cretans, even those for whom the

Muse, the goddess, placed sweet song in their breasts. $514-519$

While the verb $\ddot{\alpha} \gamma \omega$ does not appear in this description, the word $\hat{\eta} p \chi \varepsilon$ has a similar force, as Apollo "begins," or leads off, the procession..$^{9}$ Apollo's leadership, in this episode, is primarily spatial. In the form of a dolphin, he leads the

8 Or, "like the paean-singers"; see Rutherford 2001: 74; Richardson 2010: 148.

9 For $\dot{\xi} \xi \dot{\alpha} \rho \chi \omega$ and related verbal forms as terms for choral leadership, see Archil. fr. 12oW, [Hes.] Sc. 205-206; Homeric Hymn to Artemis 14-18; Pind. Nem. 2.25. 
men to Krisa. As a god, he leads them in musical procession to the sanctuary itself. The Cretan leader, however, retains a kind of political leadership defined by his relationship to his group.

As the passage above also indicates, the ritual accommodates specifically Cretan modes of expression. The men sing paeans to Apollo in the mode typical of their homeland, expressing themselves as Cretans even as they process to their new and permanent home (517-519). The paean itself thus represents both the authority of the god and the preservation of local modes of expression within a choral context. This is consistent with Catherine Bell's conceptualization of "ritualization," a framework for understanding choreia that has been particularly fruitful in the study of archaic and classical Greek performance. ${ }^{10}$

Bell identifies two major dimensions of ritualization. The first, she argues, is the "projection and embodiment of a structured environment," accomplished by "ritualized agents," i.e., participants. ${ }^{11}$ These ritualized agents, however, "do not see themselves as projecting schemes; they see themselves only as acting in a socially instinctive response to how things are."12 I would argue that the procession to Delphi, both as depicted in the Homeric Hymn to Apollo and in a more general conceptual sense, clearly and visibly embodies a specifically structured worldview. The movement of a procession delineates a relationship between center and periphery, as the processional group moves from the margins to the center, or, occasionally, vice-versa. ${ }^{13}$ The participants use their own bodies and movements to display and enact a specific spatial relationship.

In the Homeric Hymn, the Cretan sailors' organized movement towards Delphi emphasizes the site's position as the omphalos, the center of the Greek world. We will see that this spatial organization is highlighted in Paean 6 as well, for that song opens by mentioning landmarks near the entrance of the shrine

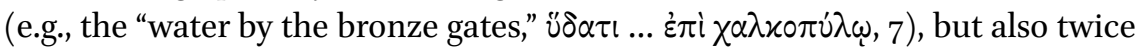

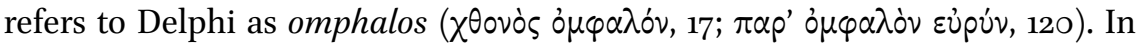
the Hymn, Apollo's position at the head of the procession symbolically asserts his role as the agos, or leader. As Bell suggests, the Cretan men act in basically socially instinctive ways- they obey Apollo's commands, and, in a very prac-

\footnotetext{
10 On the utility of Bell's model for the study of ancient Greek ritual practices, especially choreia, see Kurke 2005; Kowalzig 2007b: 32-43; Mackil 2013: 152-156; Olsen 2015.

11 Bell 1992: 207.

12 Bell 1992: 208.

13 Procession from a polis to a rural shrine is an example of the latter: see de Polignac 1984, esp. 101-108, for conceptual analysis of processional routes generally. For related readings of poetic representations of processions, see Dougherty 1994; Connor 2000.
} 
tical sense, they follow him to Delphi because he is the only one who knows where he is. But their actions project and embody a specific sense of social and cosmic order.

Bell, however, also identifies a second key dimension of ritualization. She contends that "a participant, as a ritualized agent and social body, naturally brings to such activities a self-constituting history that is a patchwork of compliance, resistance, misunderstanding, and redemptive personal appropriation of the hegemonic order."14 She thus asserts that an individual's experience as a participant in a ritual practice is actually far more complicated than the apparent projection of a particular cosmic scheme. Bell makes the related observation that "ritualized practices, of necessity, require the external consent of participants while simultaneously tolerating a fair degree of internal resistance."15 This second aspect of ritualization helps articulate how the model constructed by the Homeric Hymn to Apollo is able to leave space for the personal and the local even within the larger framework of divine, choral worship.

As we have seen, Apollo's transformation of the Cretan sailors into Delphic priests is a powerful act of divine authority. By interrupting the men in the midst of their journey, Apollo displaces their personal agency in favor of a migration accompanied by significant political and religious symbolism. By participating in a ritual that symbolically affirms Apollo's leadership and the centrality of Delphi, the Cretans do exactly what Bell suggests when she says that "specific relations of domination and subordination are generated and orchestrated by the participants themselves simply by participating."16 But Bell also remarks that ritual participants bring their own "self-constituting histories," their own patterns of both "compliance and resistance," to their ritualized practice. ${ }^{17}$ This is what happens when the Cretan sailors incorporate their local

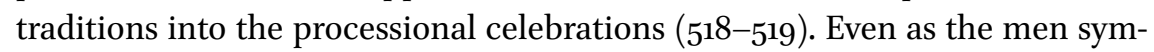
bolically affirm Delphi's centrality and Apollo's authority, they also maintain certain elements of their local affiliations and identities. A striking moment of temporal confusion in the narrative may even be read as part of this strategy. On the one hand, Apollo has just established his shrine at Delphi, and so this procession constitutes the first performance of a paean in honor of Apollo at this site. Yet the Hymn also describes the processional song as "like the paeans

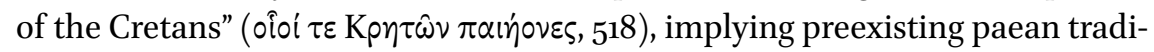
tions on Crete. Paeanic invention and innovation is thus ascribed to both the

\footnotetext{
14 Bell 1992: 208.

15 Bell 1992: 221.

16 Bell 1992: 208.

17 Bell 1992: 208.
} 
Cretans and Apollo, another way in which the Hymn presents choreia as a delicate balancing act, a ritual practice that symbolically affirms certain notions of cosmic and social order while simultaneously maintaining "the autonomy of individuals [and] subgroups."18

Bell's model of ritualization is consistent with Sklar's understanding of kinesthesia as embodied cultural knowledge. Specifically, Sklar explores how embodied sensory perception figures into the experience of memory. ${ }^{19}$ She suggests that our memories of embodied experiences-like dance or performance-are not pure or unmediated. Rather, different people "access memory via different sensory modalities," and one can often access or experience memory via one mode, but represent or describe it in another. ${ }^{20}$ For Sklar, the distinction between an individual's personal experience of embodied remembrance and the often-verbal representation thereof is crucial. The former is generally more visceral and kinesthetic, whereas the latter is heavily conditioned by cultural hierarchies of sense perception-for example, in much of western culture, an emphasis on the primacy of vision and visual metaphor. ${ }^{21}$ Sklar argues that kinesthesia, the sensation of one's own bodily presence, tension, and movement, constitutes an important form of cultural knowledge. ${ }^{22}$ Significantly, she suggests that embodied recollection and perception constitute an intimate and individual kind of knowledge, forming experiences that can both conform to and resist dominant ideological narratives. ${ }^{23}$

Sklar's conception of embodied remembrance may be understood as one form of the "self-constituting" personal history that a participant, in Bell's

18 Bell 1992: 222.

19 E.g., Sklar recounts a teaching anecdote (meditative remembering of an incident related to dance), which concludes with her asking students: "What was your dominant mode of remembering? What sensory modality emerged to trigger memory? Sound, like music or words in your mind's ears? A visual image of a setting or of yourself moving? A kinesthetic sensation of movement or of a particular dynamic of movement? And which sense was easiest to fill out once you tried to retrieve the event in detail?" (2008: 86).

20 "Richard Bandler and John Grinder ... have shown that different people access memory via different sensory modalities. Further, the sensory mode by which an individual accesses a memory is often different from the one in which he or she represents the memory" (Sklar 2008: 86).

21 Sklar specifically suggests kinesthesia "has been entirely omitted from the western sensorium" (2008: 87). For recent approaches to sense perception and hierarchies thereof in the ancient world, see, e.g., Porter 2010; Peponi 2012; Butler and Purves 2013; Bradley 2014; Squire 2015 .

22 Sklar 2008.

23 See especially Sklar 2008: 91. On this point, see also Noland, who characterizes gesture as a vital site for both the "embodiment" and "testing" of "cultural conditioning" (2009:2). 
model, can bring to ritual observance. The Cretan men outwardly embody the divine authority of Apollo, as their procession points toward his shrine and makes visible his performative leadership. Yet they remain linked with their community of origin through the political organization of their group under their established agos and the Cretan quality of their paean. Moreover, the Hymn links the local with the personal. The men's ties to Crete are expressed specifically in terms of their "fine homes" ( $\delta \omega \mu \alpha \tau \alpha \kappa \alpha \lambda \dot{\alpha}, 477)$ and

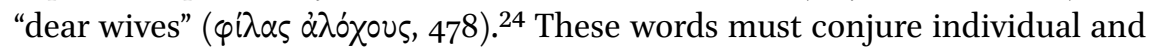
varied memories-each man surely possesses his own home, his own wife. Likewise, we might imagine that each man experiences the paean in his own personal way: just as ritual choreia accommodates both divine panhellenism and local performance idiom, so too may it allow for individual variations within a shared experience. "Paean," like "home" or "wife," is a term that can encompass both common and personal meaning. Moreover, Sklar's analysis suggests that it is a conscious and active engagement with embodied experience that enables the process of "personal appropriation" described by Bell. ${ }^{25}$ The Homeric Hymn to Apollo shows that paeanic choreia has the potential to facilitate that kind of ritual balancing act, but as hexameter solo song, its representation remains paradigmatic rather than actively engaged with immediate experience. In the second part of this paper, I will trace patterns of sensory and kinesthetic engagement in an actual paean, demonstrating how the interplay of personal and communal serves to define generic experience within the parameters of live performance.

\section{Embodying the Paean: The Dynamics of Pindar, Paean 6}

As I demonstrated above, the Homeric Hymn to Apollo offers a paradigm for paeanic choreia as a form of communal, embodied worship that leaves space for personal experience and appropriation. Pindar's sixth paean puts that model into practice in the service of preserving communal chorality and its embodied essence across diverse contexts for performance. To develop this claim, I will first comment briefly on the transmission and performance history of Paean 6, then turn to a close reading of the song that attends specifically to issues of sense perception, somatic experience, and the generic construction of the paean.

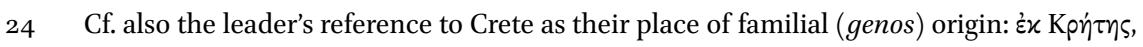

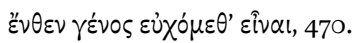

25 Sklar 2008: 91, cf. n. 16; Bell 1992: 208. 


\section{Performance and Reperformance: The Possibilities for Paean 6}

Paean 6 is a particularly good candidate for the analysis of performance dynamics due to the debate surrounding its original conditions of performance and its unusual transmission history. In order to avoid devoting too much time to a survey of these issues, I will begin by noting that I concur with Ian Rutherford's hypothesis, taken up in greater detail by Leslie Kurke, that the original performance of this paean may have been split between a Delphian chorus, performing the first two triads, and an Aeginetan one, performing the final triad. ${ }^{26}$ This scenario resolves several problems pertaining to this song, including the double transmission of the third triad: in the papyri, we find both the "full" paean (three triads) as well as the third triad alone, apparently as a prosodion, or processional song. ${ }^{27}$

There are also multiple possibilities for the reperformance of Paean 6. First, it is likely that the third triad alone was reperformed as a choral song (and perhaps also as sympotic, solo song) on Aegina by Aeginetans. ${ }^{28}$ Second, the entire song could have been reperformed, either by a chorus or at a symposium, in any number of locations. And third, I will suggest here that the first two triads alone could plausibly function as a sympotic paean in their own right. In fact, the omission of the third triad removes the most explicit references to the original Aeginetan theoria, thereby creating a song that evokes paeanic, Apollonian performance in a general sense and enables the singer to sidestep thorny questions of Aeginetan politics and affiliation. To be sure, we do not find

26 Rutherford 2001: 337-338; Kurke 2005.

27 POxy. 841 has all three triads, with the marginal title (discovered and discussed by Rutherford 1997) identifying the third triad as a prosodion -in a sense, therefore, we do not have a version of the paean that actually presents the song as a single cohesive whole. POxy. 1792 has just the third triad, with a different colometry: D'Alessio 1997 argues that this is a volume of prosodia. Recent discussions (with earlier bibliography) include Rutherford 2001: 333-338; Currie 2005: 322-325; Kurke 2005.

28 See Kurke 2005: 119-124 for one scenario, closely connected with the sacred landscape of Aegina. On the ideological force of such reperformance (not necessarily exclusive of Kurke's approach), see Fearn: "yet the separate transmission of the closing section of Paean 6 as an Aeginetan prosodion might also be a sign that original theoric thrust of the paean was capable of redirection for epichoric effect by Aeginetan elite administration, through separate and repeated subsequent performances. The reference to 'the excellence of righteous networking', $\tau \dot{\alpha} \nu \theta \varepsilon \mu i \xi \varepsilon v 0 \nu \dot{\alpha} \rho \varepsilon \tau[\dot{\alpha} \nu$, at line 131 in the prosodion section emphasizes the theoric impact of the Delphic paean, but through re-performance, could serve separately, though in a subtle way, to celebrate the current Aeginetan theoric administrators as organizers of the ongoing tradition of ritual pilgrimage" (2011a: 203). 
the first two triads transmitted independently. But the fact that the third was apparently seen as "detachable" suggests that the first two could also comprise a proper song in their own right. I will discuss below how the internal logic of the song supports this hypothesis, and my reading here will be limited to the first two triads as a complete sympotic song. ${ }^{29}$ I will begin, however, with a consideration of the sensory and somatic imagery of the first triad of Paean 6 , exploring how the song works to activate the embodied memories of its listeners.

\section{Song and Sense Perception}

In this section, I will be looking closely at the ways in which Pindar's Paean 6 , as reperformed at a symposium, rekindles somatic memories of choral performance in its audience. First, however, I want to comment briefly on the distinctions I am drawing between the poet, the speaking ego of the song, and the sympotic singer. Kurke has examined the unique qualities of this paean's ego in its choral context, arguing that the first triad in particular serves to establish the speaker as an "authoritative outsider" — distinct from the chorus — who effectively mediates between the various groups involved in the ritual performance of the song. ${ }^{30}$ On one level, even when relocated from Delphi to a symposium elsewhere, the characterization of the speaking voice retains this role. But the distinctiveness of this paean's speaking voice also facilitates the transition from Delphi to such sympotic contexts. As Kurke notes, the speaking ego is positioned outside of the Delphian chorus, as a figure possessed of his own independent mantic authority and "honors" $(\tau \mu[\alpha] \hat{\imath} \varsigma, 11) .{ }^{31}$ Yet his relationship to the Delphian chorus is also positive, consolidated via the imagery of reciprocal kinship ( $\tilde{\varepsilon} \tau \alpha \iota \varsigma, 10)$. A solo singer can thus seamlessly take up this song (at least in its first triad), adopting a fictive position as the singular internal speaker who is nevertheless figured in positive relation to the larger (now also fictive) chorus.

Beginning with the first triad of Paean 6, let us now consider how it operates, not as choral song with a prominent, poetic ego, but as the address of a sympotic singer to his immediate comrades. Since the song does not lose its strong

29 I do not mean to suggest that this is the only configuration of the song available for sympotic reperformance, merely that this is the version I have chosen to focus on as my "case study" for this paper.

3о Kurke 2005, esp. 104-119.

31 Kurke 2005: 104-105. 
sense of place, time, and occasion, I want to suggest that it creates a fictional space wherein the singer presents himself as authoritative speaker, enabling the audience to imagine themselves as choral performers.

It is plausible that sympotic audience members would be inclined to imagine themselves as choreuts, since Greek men of the late archaic and early classical periods had many opportunities to watch and perform choreia. Paeans in particular were performed at major festivals as well as more intimate sympotic settings. ${ }^{32}$ I suggested above that choral performance modes constituted a kind of "embodied cultural knowledge" for ancient Greeks—experiences that could be-and certainly were-spoken about and described at length, but would also have been viscerally, kinesthetically "known." In a sympotic context, the rich sensory imagery of the first triad of Paean 6 serves to cue the audience's embodied remembrance of their own past performance experiences, including but not limited to paeanic ones, thereby drawing them into a particular relationship with the song itself. ${ }^{33}$

The speaking voice of the song first locates his appeal to the gods within "holy time" ( $\left.\dot{\varepsilon} \nu \zeta \alpha \theta \dot{\varepsilon} \omega \ldots \chi \chi \chi^{\prime}{ }^{\prime} \nu \omega, 5\right) .{ }^{34}$ This recalls, for the audience, the special temporality of ritual performance - the time set apart from ordinary life for the express purpose of worship and celebration. ${ }^{35}$ The speaker then remarks that "having heard, by the water from the bronze gates, the murmur of the Kastalian

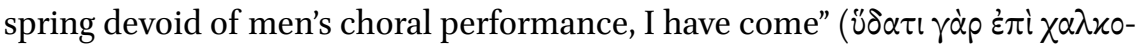

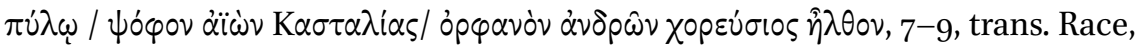
modified). The listening symposiasts are relocated to the entrance of the sanctuary at Delphi, prompted to imagine the specific features of architecture and landscape - bronze gates, murmuring spring of Kastalia — that they have pre-

32 See Rutherford 2001: $23-83$ for an overview of paeanic performance contexts and configurations. I focus here on elite listeners with personal experience of choral paean-the audience most explicitly addressed by this song. But a study of the possible effects of such songs upon other audiences present at a symposium (servants, slaves, hired entertainers) would be another desirable (if largely speculative) project.

33 See Eckerman 2014 for the analysis of a similarly sensory evocation of space and place in Pindar's Pythian 6.

34 I use Rutherford's (2001) text of Paean 6. Longer translations are by Race (1997), occasionally modified.

35 E.g., Kurke suggests that "we can see the elaborate form and production of choral song and dance as precisely a means of 'making special the everyday' - a cultural practice that marks off and differentiates a particular space and time from the ordinary, while it serves to form and reproduce ritualized bodies in action" (2005: 84). Cf. also Kowalzig, who observes that "the ability to transcend time is not only a feature of ritual, but one of its strategies" (2007b: 41). 
sumably seen and heard during their own trips to the shrine. ${ }^{36}$ The song thus engages the listener's visual and aural memory of the approach to the sanctuary.

While Pindar's chosen word for "sound"— - ó $\varphi \circ$, line 8-may be used for a fairly wide range of noises, two distinctive uses are relevant here. On the one hand, it has clear musical connotations. Sappho, for example, describes the psophos of castanets that accompanies the song of maidens in a wedding procession for Hector and Andromache (fr. 44.24-26). Euripides, in Bacchae, refers to the "psophos of the Lydian lotos-pipe," and in Cyclops, mentions the "psophos of the Asian kithara." ${ }^{37}$ At the same time, it is also used pejoratively to refer to weak, ineffective, or "empty" noise. In Euripides' Heracles, for example, Amphitryon laments that he has become "nothing but the psophos of the tongue" (

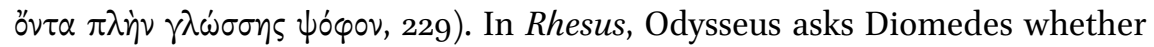

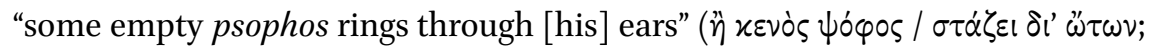
565-566). In Paean 6, the reference to the psophos of the Kastalian spring may thus endow the gurgling water with its own latent musicality. But linked fur-

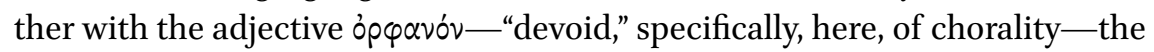
sound of the spring is subordinated to the superior musicality of the coming choreia. The language of the song turns the audience's attention to sound in general while simultaneously reinforcing the preeminence of choral song and dance. The song's first ten lines thus employ visual and aural imagery in order to recreate for the audience the experience of heightened sensation that accrues in the moments of performance.

Paean 6 now pivots to a vivid image of another, projected chorus, as the speaker explains:

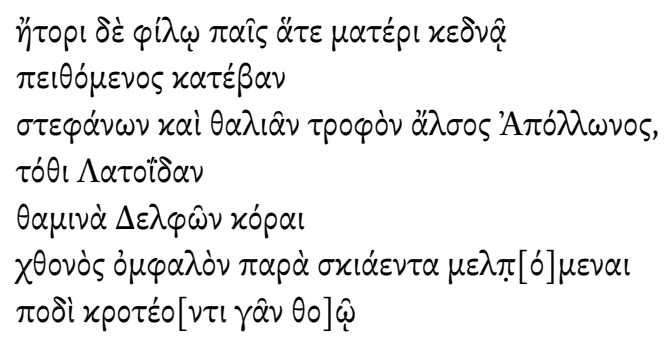

for in heeding my own heart, as a child obeys his dear mother, I have come

$3^{6} \quad$ On this imagery, see also Eckerman 2014: $36-37$.

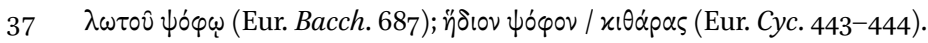


to Apollo's precinct, nurse of crowns and feasts, where the maidens of Delphi often sing to Leto's son at the shady navel of the earth and beat the ground with a rapid foot.

$12-18$, trans. RACE

These lines continue the pattern of attention to sensory perception, prompting their audience to recall their own embodied experiences of Delphic festivitycool shade (17), the combined sonic-and-visual experience of choreia (18). Even if the paean is not specifically invoked, the Delphic setting and references to Apollo gesture toward the genre.

But these lines also feature distinctly feminine focalization, as they thrice appeal to female roles and maternal-feminine descriptive terms. As Eva Stehle has noted, "images of nurture prevail." 38 The speaker first figures himself as a "child" obedient to his "dear mother" (12). He then describes Apollo's sanctuary as the "nurse" (14) of crowns and feasts. And while he initially refers to the god by his own proper name ('A $\pi \dot{0} \lambda \omega \omega \nu \circ \varsigma, 14)$, he follows this with an immediate reference to the god via his matronymic $-\Lambda \alpha \tau \sigma^{i} \delta 0 \alpha v$, "son of Leto" (15). This turn to the feminine strengthens the parallel between the described chorus of maidens ( $x^{\prime}$ pal, 16) and the original chorus of Paean 6 itself, both of whom sing and dance for Apollo at Delphi. By invoking a series of feminine descriptors in the lines preceding the description of the girls' chorus, the singers of Paean 6 are placed in a close, empathetic relationship with these projected female performers-singing, for the space of these few lines, in a notably femaleoriented mode.

The song also encourages its performers and listeners to imagine their viewing of the Delphian korai as a thoroughly embodied experience. The girls are

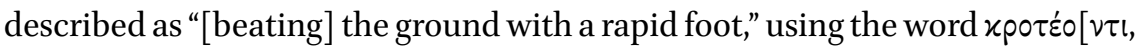

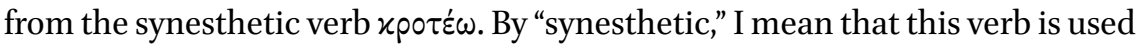
to denote both sound (a rattling or beating noise) and motion (the action of rattling or beating). It thus prompts the listener to imagine, simultaneously, the sound of the dance and the motion of the bodies in performance-again,

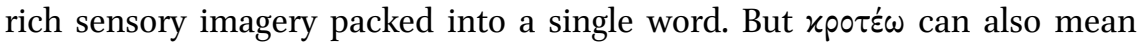
"to applaud."39 It thus effects a kind of collapse between the performers and

38 Stehle 1997: 142.

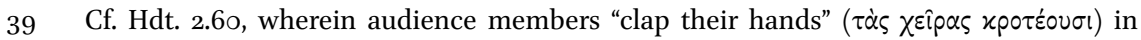
response to a musical performance. 
the audience - casting the motion of the dancing foot ( $\varkappa p \circ \tau \varepsilon \dot{\varepsilon} \omega)$ as analogous to

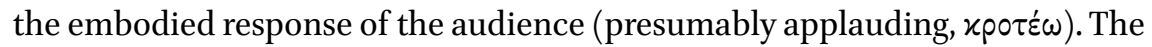
description encourages its performers and listeners to imagine a shared experience of embodied or kinesthetic empathy, whether in the actual moment of performance or in the recollection, prompted perhaps by the reperformance of this song, of prior experiences of spectatorship. ${ }^{40}$

The next thirty lines of the song are missing. But sensory imagery resurfaces in the surviving eleven lines of the triad, wherein the speaker "longs [perhaps to

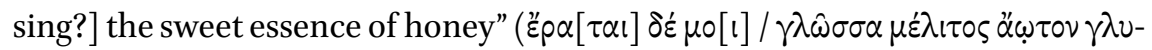
xúv, 58-59) — vividly evoking taste, possibly combined in a synesthetic image of taste, vocalization, and sound. The references to the "virgin Muses" ( $\pi \alpha p-$

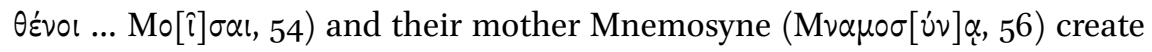
a kind of ring composition when combined with the song's opening invoca-

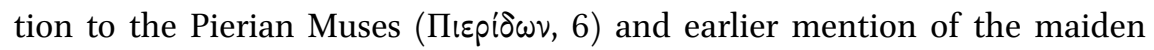
performers of Delphi (16-17). The naming of Mnemosyne, or Memory, may further act as a kind of metacommentary on the work of recollection that the song encourages in its listeners. Given this return to multisensory imagery, we might reasonably posit that the theme persisted throughout this portion of the song.

The first triad of Paean 6 thus engages the embodied memory of the audience on multiple levels, reminding them of what it feels like to watch and perform choreia at Delphi. The abundant references to Apollo and Delphi point to the paean and may well have primed the audience to situate their embodied recollections within the framework of that specific genre. Yet many of the features that I have discussed here are characteristic of Greek choral performance broadly, not the paean in particular. The performers are invited to feel empathy with maiden song (lines 12-18), and at least in the extant text, there is no characteristic paean-cry (ie paian). This song, in a reperformance context, thus relies upon shared cultural knowledge of choreia and its sensory experience, as well as a general knowledge of Delphic topography, but it does not yet insist that the listener focus specifically on the experience of the paean. This changes, however, in the second triad, which chronicles Apollo's conflict with Achilles and Neoptolemus and builds toward the explicit invocation of the paean and its characteristic refrain. 


\section{Divine Action, Mortal Bodies}

The early, fragmentary portion of the second triad addresses events from the Trojan War. While the state of the papyrus prevents us from fully restoring the text, there is a reference to Apollo, "the far-shooter," acting "in the mortal

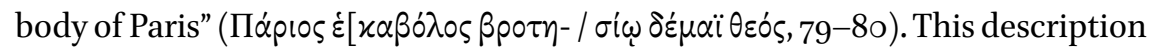
stresses that Paris retains his corporeality ( $\delta \varepsilon \dot{\varepsilon} \mu i i)$, but his agency is transferred to Apollo. This is significant because it is consistent with the somatic experience of choral performance as generally conceptualized in ancient Greecehuman bodies move and dance, but their choreographed action is conceived as intimately linked with divine will. ${ }^{41}$ Likewise, in the final episode of the triad, the song claims that Apollo killed Neoptolemus at Delphi $\left(\varkappa \tau \alpha \dot{\alpha} v \varepsilon \nu /\langle\dot{\varepsilon} \nu\rangle \tau \varepsilon \mu \varepsilon^{\prime}\right] \nu \varepsilon i ̈$ $\varphi(\lambda \omega, 119-120)$, although a version of the same myth in Pindar's Nemean 7 features a mortal man as the killer of Neoptolemus. ${ }^{42}$ As Rutherford observes, the discrepancy is minimized if we understand Apollo as capable of acting via the bodies of his followers. ${ }^{43}$ The song's assumption of continuity between the body of the god and the bodies of mortals has particular relevance for the study of ritual performance.

As we saw in the Homeric Hymn to Apollo, the choral performance of paean may be conceived as a way of granting the god ultimate authority over the bodies of his followers - the ability to direct and organize their movements in order to project a particular image of divine order. At the same time, performers may retain important markers of individual and local identity. Likewise, the imagery of the first triad of Paean 6 encourages the communal appreciation of choreia and embeds its listeners within the performance landscape of Delphi. But its attention to sensory experience (cool shade, the sensation of the foot striking the earth) also prompts listeners to turn inward, toward the recollection of personal kinesthetic experience. The second triad continues in the same vein by highlighting the complex relationship between divine authority and human bodies, as when Apollo acts "in the mortal body" of Paris $(79-80)$. As in the Homeric Hymn to Apollo, the god exercises control over a man's body without entirely usurping his personal identity. The comparison I have drawn with the Homeric Hymn to Apollo was intended to highlight how choreia in general, and the paean in particular, maintain a balance between individual and local iden-

\footnotetext{
41 See especially Kurke 2013 a.

42 On the relationship between Nemean 7 and Paean 6 (both contra the notion that Nemean 7 is an "apology" for Paean 6), see Burnett 1998: 504-514; Currie 2005: 315, 321-331.

43 Rutherford 2001: 314.
} 
tities and the articulation of divine authority through communal action. I have now traced how Paean 6 gestures in a similar direction through the sensory imagery of the first triad and the relationship between the god and the mortal body mentioned at the beginning of the second. I will now contrast those patterns with the negative depiction of Neoptolemus in the later portion of the second triad of Paean 6.

\section{A Transgressive Leap: Neoptolemus and Apollo}

Paean 6 alleges that Apollo denied Neoptolemus a safe homecoming because "he killed aged Priam, who had leapt up on the altar of Zeus Herkeios" ( $\gamma \varepsilon \hat{\varepsilon}[$ pov $] \theta^{\prime}$

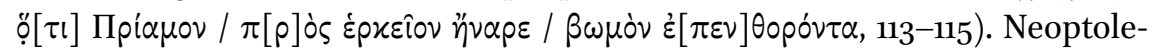
mus' fatal transgression is thus aligned with his active physical pursuit of Priam, who, despite being "aged" ( $\gamma^{\varepsilon}\left[\right.$ pov] $\theta^{\prime}, 113$ ), is described as "having leapt"

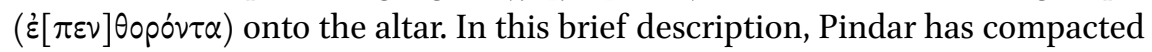
a rich tradition surrounding Neoptolemus' actions at both Troy and Delphi.

The sources I am about to discuss mostly postdate Pindar's sixth paean. But given the commonalities among them, I would posit that they all draw upon an early tradition - likely part of the epic cycle. For example, both Neoptolemus and his father Achilles are frequently associated with leaping and even dancing - in Neoptolemus' case, usually in a negative, destructive, or transgressive way. Archilochus reports that Pyrrhus (an alternate name for Neop-

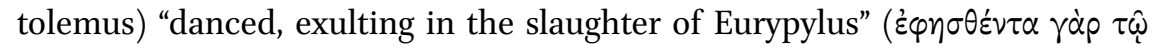

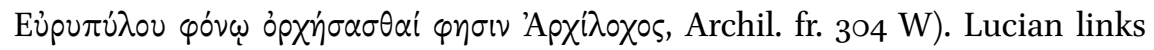
Neoptolemus' skill in armed dance with his prowess in battle, and remarks that "while Troy had been, until that point, impregnable, his dancing destroyed it

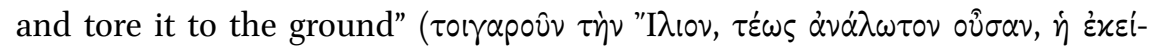

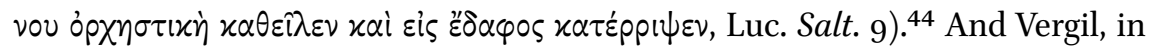
his account of Priam's death, stresses that Neoptolemus deliberately dragged (traxit, 551) Priam to the altar to kill him, a stunning act of violence and transgression of Greek social norms. ${ }^{45}$ Neoptolemus is thus associated with inappropriate kinds of movement: dancing in celebration of slaughter and killing within the sanctuary of a god.

44 See Borthwick 1967 for many other relevant parallels.

45 Verg. Aen. 2.550-551 (hoc dicens altaria ad ipsa trementem / traxit et in multo lapsantem sanguine nati). On the death of Priam in Greek art, see Anderson 1997 passim (with discussion of Homer and the epic cycle as well); Hedreen 2001: 64-9o. On the depiction of Neoptolemus' murder of Priam as an act of sacrilege, see Miller 1993: 452; Rehm 2002: 247-248. 
In Paean 6, Neoptolemus murders Priam on the altar of Zeus at Troy (113115), and Apollo retaliates by slaying Neoptolemus at Delphi (119-120). Given the association of Neoptolemus with jumping, leaping, and dancing, it is tempting to read the unlikely description of the elderly Priam "having leapt" ( $(\dot{\varepsilon}[\pi \varepsilon v]-$

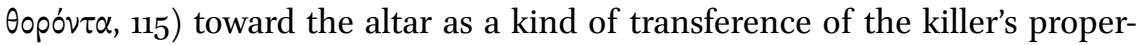
ties onto the victim. The description underscores Neoptolemus' transgressive movement and action, striding into the sacred space of Troy and slaying its king upon the altar. Euripides, in Andromache, describes Neoptolemus similarly leaping and fighting at the altar at Delphi (1135-1140), immediately prior to his death.

By highlighting the inappropriate action of Neoptolemus at the altar of Zeus at Troy, the chorus of Paean 6 calls attention to its own proper movement within the divine space of Apollo at Delphi. A subsequent sympotic audience is thereby encouraged to consider its own corporeal allegiance, and ideally engage in an embodied, kinesthetic remembrance of correct ritual performance. Through their bodies and actions, paean-performers and followers of Apollo manifest the authority of the god while still retaining their individual identities and personal experiences. Neoptolemus, by contrast, is fatally out of sync with the god, engaging in transgressive kinds of motion and action and suffering death as a consequence. ${ }^{46}$

\section{Experiencing the Origins of the Paean}

But in his depiction of Neoptolemus, Pindar does not just draw a contrast between communal choral ritual and an individual act of violent transgression. He also alludes to the origins of the paean, thereby drawing the performing chorus and the listening audience into a closer relationship with the genre itself. As I discussed above, the Homeric Hymn to Apollo offers one account of the first performance of paeans at Delphi, and Paean 6 is similar to the Hymn in its representation of choreia as a form of communal embodiment that reinforces cosmic order while leaving space for individual kinesthetic experience. But Pindar's sixth paean alludes to a different aetiology for paean performance at Delphi-one which serves to cement the links between the performing chorus and the imaginative and empathetic sympotic audience.

46 See Kurke 2005: 100 on Neoptolemus' transgressions at Delphi, as well as Kowalzig 2007b: 192-201 for another angle on Neoptolemus' fraught relationship with Delphi and role as a paradigm figure for failed theoria. 
Rutherford suggests that "the conflict between Apollo and Neoptolemus [in Paean 6] is analogous to the Pythoctonia." ${ }^{47}$ That is, Apollo's defeat of the transgressive hero at Delphi reenacts his defeat of the monster Pytho and reinstates the god's authority over the shrine. Moreover, Apollo's defeat of Pytho is specifically relevant to the paean itself: in one version of that myth, Apollo's triumph over the serpent is also the origin of the paean. According to Atheneaus, for example, Leto calls upon her son to "shoot, child!" ("ॄ $\pi \alpha \hat{\imath}$ ) when the monster attacks, referring to Apollo's skill with the bow. Athenaeus then claims that this phrase is modified over time, such that the rough breathing on the initial word ("i $\pi \alpha \hat{\imath})$ becomes smooth (" $\varepsilon \pi \alpha \hat{\imath})$, and is eventually transformed into the characteristic paean cry (ì $\left.\pi \alpha \iota^{\prime} \omega\right)$ ). ${ }^{48}$ I am not concerned here with the plausibility of this transformation on linguistic grounds; rather, I want to suggest that it constitutes one of several origin-myths for the paean likely familiar to an archaic audience. While I have drawn from Athenaeus' explanation here, Rutherford makes a compelling case that this aetiology would have been known to Pindar (and his audiences). ${ }^{49}$

Rutherford further argues that, if Apollo's conflict with Neoptolemus is analogous to the Pythoctonia origin-myth of the paean, then "the present song [that is, Paean 6 itself] is analogous to the original $\pi \alpha i \alpha \nu$... thus Pindar recalls the origins of the genre."50 I would expand this point to say that Paean 6 takes its performers and audiences along on a descriptive journey culminating in the reinvention of the paean. The strong sensory evocation of Delphic festivity and choreia in the opening triad and the assimilation of the follower's body to the body of the god in the second triad work together, such that the listener is encouraged to imagine himself as Apollo's embodied agent. The contrast with the transgressive corporeality of Neoptolemus-who has no divine patron in this song - thus acquires an additional force: Apollo and his followers, through the performance of paean, repeatedly triumph over their enemies.

The final lines of the second triad- "sing now, young men, sing now the mea-

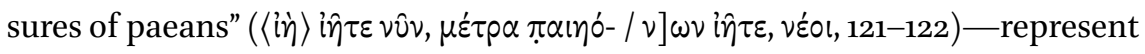
an important climax, dense with meaning: the moment when the song fully comes into being as a paean. ${ }^{51}$ The original choral performers reenact the exhilarating moment of generic innovation, crying out in response to Apollo's defeat of Neoptolemus just as Leto cries out at the moment of her son's triumph over

47 Rutherford 2001: 319. See also Rutherford 1991 for an earlier formulation of this argument.

48 Ath. $15 \cdot 701 \mathrm{c}-\mathrm{e}$.

49 See Rutherford 2001: $35^{-26}$, 318-319.

5 o Rutherford 2001: 319 .

$5^{1} \quad$ See further Rutherford 2001: $315-320$. 
Pytho. The term $\mu \varepsilon \dot{\varepsilon} \tau \alpha$ highlights the regulated, communal motion of the chorus, revisiting the earlier contrast between the organized movement of ritual and the violent actions of a transgressive individual like Neoptolemus. And the vocative véol, "young men," does double duty: in the original performance context, it functions as choral self-address, shifting attention from mythic narrative back to contemporary ritual context. In a subsequent sympotic context, it opens the song up for further reflection and engagement, addressing the

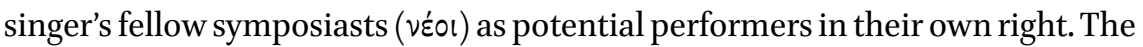
paean-cry at the end of the second triad thus concludes the song with a powerful affirmation of the genre. These two triads stand alone as a complete song, with a length and internal logic appropriate to a symposium.

\section{Conclusion}

Mikhail Bakhtin posits that an utterance's conception of its addressee-its addressivity - is a constitutive marker of speech genre. ${ }^{52}$ On one level, this is consistent with the occasional model of Greek song genre, which maintains that a song's conception and representation of its audience is an important component of the larger framework of "performance context." ${ }^{33}$ In this chapter, I have argued that choral song genre is constituted, not by a merely abstracted sense of the addressed audience, but rather by conscious reference to the audience as an embodied presence. In Paean 6, we can see how visual, sonic, and kinesthetic cues encourage a process of embodied remembrance of Delphic choreia that culminates with the explicit performance of the paean refrain. Throughout the song, the balance between communal and individual experience characteristic of Greek choral performance is rekindled in the body of the listener, even if that listener now reclines at a symposium instead of standing in

$5^{2}$ Bakhtin 1986b: 95-99. We might compare this with Frow's analysis of "generic cues" (2015: 119-124), wherein the author provides a nursery rhyme as an example and observes that its genre "is defined, above all, by its situation of address: it is characteristically spoken or sung, to or by a child, and is usually short, strongly rhythmical, and may involve a play with nonsense words; it may accompany such activities as skipping, slapping, or counting, or being sung to sleep. In a sense it is a conglomerate genre, and may include such kinds as ballads, riddles, proverbs, street cries, skipping songs, lullabies, or counting out rhymes" (2015: 120). Cf. also Jauss 1982 on how the expectations of an audience or reader condition the reception of a literary work (especially as discussed by Weiss in this volume).

53 E.g., the surviving portions of Alcman's partheneia display a keen awareness of their intended audience and its role in constituting the particular identity of the performing parthenoi (see Stehle 1997: 71-93; Peponi 2004). 
the shade at Delphi. Paean 6 thus relies upon the complicity and engagement of the audience in its process of reconstituting and reinstantiating the choral paean within the imaginative space of the symposium. In this sense, the notoriously flexible paean genre displays a crucial continuity in its addressivity. On the one hand, the occasion of Paean 6 may have shifted significantly over the life of the song: from Delphi to a symposium, from performance by a DelphianAeginetan chorus to that of a solo singer from (or in) another place entirely. At the same time, the way in which it conceives of and addresses the embodied, sensory presence of its audience remains remarkably consistent. 